\title{
Determinants of farm level market supply of tomatoes in Fogera district, South Gondar Zone of the Amhara Region, Ethiopia
}

\author{
Hawlet Mohammed Kassaw ${ }^{1, *}$, Zewdu Berhanie ${ }^{1}$ and Getachew Alemayehu ${ }^{2}$ \\ ${ }^{1}$ Bahir Dar University, College of Agriculture and Environmental Science, Department \\ of Agricultural Economics, Bahir Dar, Ethiopia \\ ${ }^{2}$ Bahir Dar University, College of Agriculture and Environmental Science, Department \\ of Plant Science, Bahir Dar, Ethiopia
}

\begin{abstract}
S
This research attempted to analyze the determinants of market supply of tomato in Fogera district, South Gondar zone, Amhara Region of Ethiopia. Tomatoes generate income for the poor farmers of Ethiopia. Primary and secondary data were collected. The primary data was generated though a household survey $(\mathrm{N}=235)$, a pre-tested structured questionnaire and a key informant interview using a checklist. The data were analyzed using multiple linear regression model. The model results showed livestock ownership, size of land allocated for tomato, access to credit, income from non-farm/off-farm activities and use of improved seed significantly affected quantity of tomato supplied to the market. The findings indicated the need to encourage off/non-farm income activities, strengthen access to improved varieties of tomato, use technologies that can improve the production and productivity of tomato, and expand the access to credit.
\end{abstract}

Keywords: Market supply; Multiple Linear Regression; Determinants; Tomato producers.

DOI: https://dx.doi.org/10.4314/ejst.v14i2.5

\section{INTRODUCTION}

Ethiopia's various climates and altitudes favor various agricultural activities. The country's many lakes and perennial rivers mean great potential for irrigated agriculture. The groundwater potential of the country is about 2.6 billion cubic meters (EIA, 2012). The groundwater in the country is generally of good quality and it is frequently used to water homes and farmsteads. The potentially irrigable land area of the country is estimated at 10 million hectares, out of which only about $1 \%$ is currently under irrigation. Most of the soil types in fruits and

${ }^{*}$ Corresponding author: hawlet.mohammed08@gmail.com

(C)This is an Open Access article distributed under the terms of the Creative Commons Attribution License (http://creativecommons.org/licenses/CC BY4.0) 
vegetables producing regions of the country range from light clay to loam and are well suited for horticultural production (Addisu Hailu, 2017).

According to CSA (2015), vegetable production is becoming an increasingly important activity in the agricultural sector of the country following the development of irrigation and increased emphases given by the government to small scale commercial farmers. Recently, due to their high nutritional value, demand for vegetables is steadily increasing in local and foreign markets, and generate a considerable amount of foreign currency earnings to the country. Commercial farms in Ethiopia used to grow vegetables over a considerable land area for years (Melkamu Bezie et at., 2017). However, out of the total land area under cultivation in Ethiopia, land under fruits and vegetables is insignificant as compared to food crops (EIA, 2012).

Tomato (Lycopersicon esculuntum Mill.) is one of most important edibles and nutritious vegetable crops in the world. It ranks next to potato and sweet potato with respect to world vegetable production. It is widely cultivated in tropical, sub-tropical and temperate climates. According to FAOSTAT (2009), 126 million tons of tomatoes were produced in the world. China, the largest producer accounted for about one-fourth of the global output, followed by the United States, Turkey, Iran, Mexico, Brazil, and Indonesia. The total area of land estimated to be covered by tomato farms in 2011/12 marketing Year was 7,255 ha with an estimated yield of 81,970 MT (11.3 MT/ha). It is estimated that more than 254, 000 farmers are engaged in tomato farming (Abu Tefera and Teddy Tefera, 2013) . It is the most frequently consumed vegetable in many countries, becoming the main supplier of several plant nutrients and providing an important nutritional value to the human diet (Willcox et al., 2003). The crop generally requires warm weather and abundant sunshine for best growth and development. The importance of marketed and marketable surplus has greatly increased owing to the recent changes in agricultural technology as well as social patterns. In order to maintain the balance between demand for and supply of food grains with the rapid increase in demand due to high population growth, urbanization, industrialization and overall economic development, knowledge on marketed and marketable surplus is essential in the process of proper planning for the procurement, distribution, export and import of agricultural products (Melkamu Bezie et al., 2017).

Marketable surplus shows the quantity left out for sale in the market after meeting the farmer's consumption and utilization requirements for kind payment and other obligations such as gifts, donations, charity, etc. The marketed surplus shows the quantity actually sold after accounting for losses and retention by the farmers if any and adding the previous stock left out for sale (Thakur et al., 1997). Vegetable production in Fogera district is largely for the market except 
potato, which is mainly used for household consumption. The production is very fragmented and uncoordinated where all growers produce similar types of crops resulting in the glut (mainly onion and tomato) typically in harvest seasons.

Based on the information obtained from Fogera District Agricultural Office (2015), vegetable marketing in the district is characterized by an inefficient market, even if there is an increasing trend in the production of vegetables for one season (fluctuated production based on price signals). It has been constrained with lots of problems such as inadequate transport network, the limited number of traders and market outlets, with inadequate capital facilities, high handling costs, weak bargaining power of farmers and underdeveloped industrial sectors, unstable prices, lack of storage facilities, lack of transportation facilities, poor linkages with traders, low quality controlling mechanisms, weak market information (outdated market information) and other factors. All these need to be further investigated thoroughly and alternative solutions be suggested and implemented to benefit producers and other marketing agents involved in the production of vegetables. To benefit tomato farmers from production and market supply, the tomato marketing system must operate efficiently.

The study was an attempt to contribute to filling the knowledge gap by identifying factors affecting the market supply of tomatoes in the study area to provide information for future planning and policy intervention.

\section{RESEARCH METHODOLOGY}

\section{Description of the study area}

Fogera is one of the districts in South Gondar Zone, Amhara Region of Ethiopia (Figure 1). The district is bordered by Dera in the south, by Lake Tana in the west, by Rib River in the north which separates it from Kemekem district, in the northeast by Ebenat, and in the east by Farta (Fogera District Agriculture Office, 2015).

Woreta town is an administrative center of Fogera district. The altitude of the district ranges from 1774 to 2415 meters above sea level. Rivers in Fogera include Gumara and Rib, both of which drain into Lake Tana. Some $44.2 \%$ of the district is arable or cultivable, about $20 \%$ is irrigated, $23 \%$ is used for pasture, $1.8 \%$ forest or shrubland, $3.7 \%$ covered with water, and the remaining $7.4 \%$ is considered degraded or others.

Based on the 2007 National Census conducted by the Central Statistical Agency of Ethiopia CSA (2007), the district has a total population of 233,529 (about 51\% 
male and 49\% female) (Fogera District Agriculture Office, 2015). With an area of $1,111.43 \mathrm{~km}^{2}$, Fogera has a population density of 205.55, which is greater than the zonal average of 145.56 persons per $\mathrm{km}^{2}$. The district is divided into 26 rural kebeles (or communes) and 5 urban kebeles. A total of 52,905 households were counted in this district, resulting in an average of 4.32 persons to a household (Fogera District Agriculture Office, 2015). Teff, sorghum, cotton, vegetables like tomato, onion, cabbage, potato and sweet potato, and sesame are important cash crops in the district.

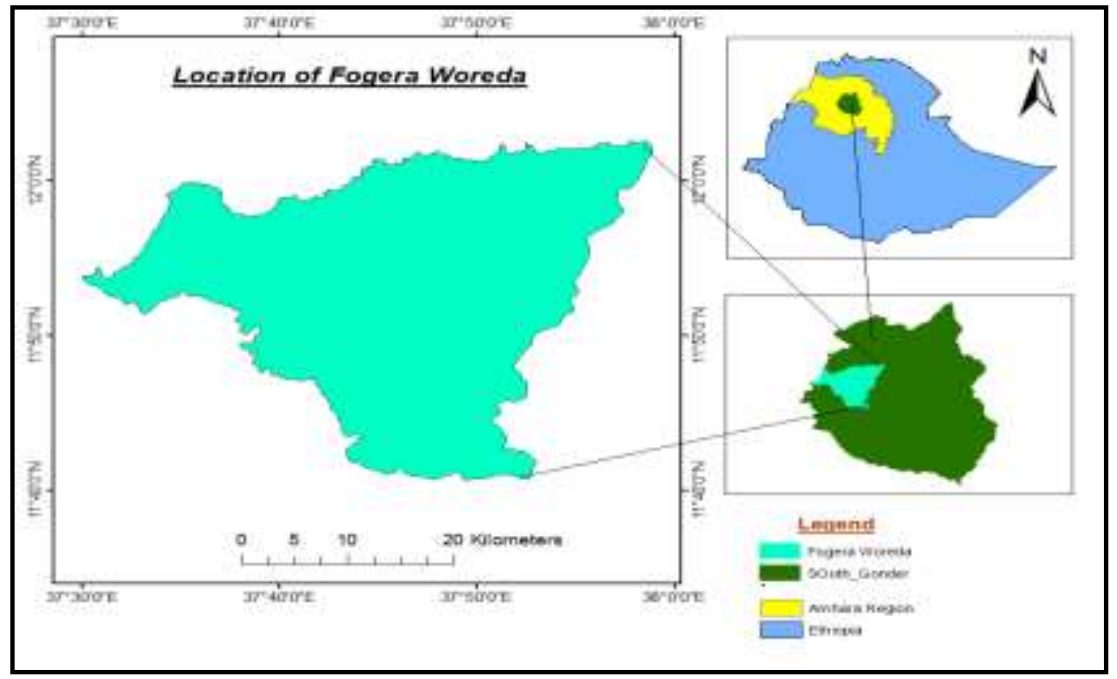

Figure 1. Location of Fogera district

Source: Adopted from (Hawlet Mohammed et at., 2019)

\section{Data type and methods of data collection}

In this study, both primary and secondary data were used. Both formal and informal survey procedures were used to collect primary data. The formal survey was undertaken through interview of selected tomato producer farmers using a pretested semi-structured questionnaire.

\section{Sampling technique and sample size}

In this study, sampling producers, two-stage random sampling technique was used. In the first stage, three from tomato grower kebeles in the district, i.e., Woreta zuriya, Tiwa and Shina kebeles were randomly selected. In the second stage, from each sampled kebele, tomato producer farmers were listed out with the help of development agents at kebele level. From these population lists, sample farmers were selected randomly based on probability proportional to size 
sampling technique (Table 1). For this study, the total sample size was determined based on the sampling formula provided by Yamane (1967). The formula used for sample size determination with a 95\% confidence level was:

$$
\begin{aligned}
& \mathrm{n}=\frac{N}{1+\mathrm{N}(\mathrm{e})^{2}} \\
& \mathrm{n}=\frac{1506}{1+1506(0.06)^{2}}
\end{aligned}
$$

Where $\mathrm{n}=$ sample size, $\mathrm{N}=$ population size and $\mathrm{e}=$ level of precision. Based on the above formula a total of 235 households wase interviewed (Table 1).

Table 1. Number of sampled households in each sample kebele $(\mathrm{N}=235)$.

\begin{tabular}{llllllll}
\hline & \multicolumn{3}{l}{ Household number } & & \multicolumn{3}{l}{ Sample size } \\
\cline { 2 - 3 } \cline { 7 - 8 } & M & F & Total & & M & F & Total \\
\hline Woreta zuriya & 685 & 30 & 715 & & 107 & 5 & 112 \\
Shina & 506 & 15 & 521 & & 78 & 3 & 81 \\
Tiwa & 260 & 10 & 270 & & 40 & 2 & 42 \\
\hline
\end{tabular}

Source: own computation, 2018.

\section{Method of data analysis}

Descriptive statistics (mean, standard deviation and percentages) and econometric analysis were used to analyze the data collected from tomato producers. In econometric analysis, since all sample tomato producers have participated in the market, multiple linear regression model was used to analyze factors affecting farm level tomato market supply. The econometric model specification of market supply function was the following.

$$
Y=X^{\prime} \beta+U
$$

Where $\mathrm{Y}$ is tomato marketed surplus, $\mathrm{X}$ is a vector of explanatory variables, $\beta$ is a vector of parameters to be estimated and $U$ is disturbance term. Tomato marketed surplus is a continuous dependent variable used in the multiple linear regression model. It is measured in quintal and represents the actual supply of tomato by farm households to the market in 2017/2018 production year.

\section{Variable specification and hypotheses}

\section{Dependent variables}

Quantity of tomatoes marketed (toputS): This was a continuous variable representing the actual amount of tomatoes supplied to the market by sample farm households during the survey year. 
Independent variables: Different variables were expected to determine quantity of tomatoes supplied to the market. A number of factors were identified that determined the marketed surplus of agricultural commodities at the farm household level (Table 2). Based on the context of the study area, explanatory variables expected to affect the dependent variable were the followings:

Education level of the household head (Edcastatus): This was a dummy variable with (literate $=1$, and illiterate $=0$ ). It is believed that if a farmer attained formal education of any level, their productivity could be enhanced as they have better knowledge than those who did not attend formal education. In addition, educated farmers are exposed to better technologies that help them increase production and market supply. There are many studies that show the relationship between education and quantity supplied to the market. Yeshitila Alemu (2012) found positive relationship between education and vegetable market supply. Similar studies conducted by Getaneh Gizachew (2005) and Rehima Mussema (2006) identified positive relationship between formal education and household market participation and marketed volume. Astewel Takele (2010) also found the more the producers of paddies got educated the more the supply market. Therefore, in this study, formal education is expected to have positive relationship with the quantity of tomato supplied to market.

Use of improved seed (IMPSEED): This was a dummy variable and took a value of 1 if a farmer used improved seed and 0 otherwise. Improved seeds are more productive and better resist diseases (Abay Akalu, 2007) and (Mebrat Tola, 2014). Therefore, the use of improved seeds was expected to have a positive effect on the tomato market supply.

Experience of household head in tomato production (TOfexp): This was a continuous variable measured in number of years of tomato production of a household. A household with better experience in tomato production is expected to produce more than the one with less experience and, as a result, he/she is expected to supply more of the produce to the market. Therefore, experience in tomato production was expected to have positive relationship with the market supply of tomatoes. Increasing farmer's experience increases tomatoes supplied to the market (Abay Akalu, 2007; Bekele Wegi, 2017).

Distance to the nearest market (Disnmkt): This was a continuous variable measured in hours of walk. If the market is close enough, that means transportation and other costs would be less, and the farmers have more information about the market. The study conducted by Dibaba Regasa (2018) on factors affecting the market supply of wheat by smallholders in Ethiopia revealed negative relationship between wheat marketed surplus and distance to market. 
As the market becomes far from the farm, the marketed surplus is expected to decrease. Thus, distance to the nearest market was hypothesized to have negative relationship with market supply of tomatoes.

Access to credit (Acrdt): This was a dummy variable that represents access to both formal and informal credit for farm-related purposes. It was measured as 1 if a farmer has access to credit and 0 otherwise. Access to credit is an important source of finance for agricultural activities of smallholder farmers (Melkamu Bezie et al., 2017). Access to credit was expected to have direct relationship with the market supply of tomatoes.

Livestock ownership (Lisvstowneship): This reflects the total livestock a farmer owns expressed in tropical livestock unit (TLU). The farmer who possesses relatively large number of livestock is expected to have more money for the purchase of agricultural inputs and again has the chance to get oxen for draught power. It also serves as an alternative means to obtain a benefit in times of crop failure(Desta Beyra, 2004). In other cases, farmers with more livestock assets have better animal manure to increase productivity and production since the manure is used for input to improve soil fertility. As a result, farmers increase quantity supplied to the market (Mahlet Abitew et al., 2015; Melkamu Bezie et al., 2017). Therefore, livestock ownership was expected to have positive relationship with market supply of tomato.

Landholding size of household (LsizeT): This was a continuous variable expressed in hectare indicating the total land owned by a farm household. An increase in the size of land is assumed to directly influence market surplus. Bekele Wegi (2017) found expanding the area for potato production increased market supply of potato. As land size a farmer owns increases, more land size would be allocated for tomato production and as a result the market supply would increase.

One year lagged price (last year price) (LP): This was a continuous variable measured in birr per kilogram (the price of tomatoes in 2016/17 Ethiopian calendar). The sign for the coefficient was expected to be positive. As the farmer saw higher price a year before, the probability to produce and supply to the market will be high. This is because many farmers are sensitive to market prices for their products and they supply in response to market signals; because it means getting higher incomes from their produce. According to the findings of Dibaba Regasa (2018), farmers studied price situation of the produce and could appropriately predict and respond to the prices by producing more that affected market supply. 
Income from non-farm / off-farm (NFI): This was a continuous variable measured in birr. The variable represents income originated from different sources other than own farm and obtained by household head, spouse and other household members. Through improving the production process, this income makes the household to expand production. Thus, income from the non-farm/offfarming sources was hypothesized to affect market supply of tomatoes positively. Nuri Lefebo (2016) found non-farm income positively related with the quantity of enset crop supplied to the market.

Table 2. Summary of hypothesized variables.

\begin{tabular}{|c|c|c|c|}
\hline Variable & Description & Measurement & $\begin{array}{l}\text { Expected } \\
\text { effect }\end{array}$ \\
\hline Educstatus & $\begin{array}{l}\text { The educational level of } \\
\text { the household head }\end{array}$ & $0=$ illiterate, $1=$ literate & Positive \\
\hline LsizeT & Area cultivated by tomato & Hectare & Positive \\
\hline Lisvstowneship & Livestock ownership & $\begin{array}{l}\text { Tropical unit } \\
\text { equivalent (TLU) }\end{array}$ & Positive \\
\hline Disnmkt & $\begin{array}{l}\text { Distance from residence to } \\
\text { market center }\end{array}$ & Hours walking & Negative \\
\hline Acrdt & Access to credit services & $1=$ Yes, 0 otherwise & Positive \\
\hline TOfexp & $\begin{array}{l}\text { Tomato farming } \\
\text { experience }\end{array}$ & Years & Positive \\
\hline LP & Lagged price & Birr/kg & Positive \\
\hline NFI & $\begin{array}{l}\text { Income from non/ off- } \\
\text { farm }\end{array}$ & Birr & Positive \\
\hline ISEED & Improved seed & $1=$ yes, $0=$ otherwise & Positive \\
\hline
\end{tabular}

\section{RESULTS AND DISCUSSION}

\section{Socio-economic characteristics of the sample households}

Socio-economic characteristics of the sampled households showed that $70.6 \%$ were illiterate (did not attend any formal or informal education) and the remaining $29.4 \%$ were literate (they attended formal or informal education) (Table 3). Though education helps farmers to analyze the benefits, costs, and risks involved in tomato production, the majority of the sample farmers in the study area were illiterate. From sampled households, about $49 \%$ used improved seeds and $51 \%$ did not use improved seeds. About $61.3 \%$ of the interviewed households had access to credit and the remaining 38.72\% did not. Credit is one way of improving smallholder farmers' production and productivity. Farmers' ability to purchase inputs such as improved seeds and fertilizer is tied with access to credit. Farmers having better access to credit can minimize their financial 
constraints and buy inputs more readily than those with no access to credit (Table $3)$.

Table 3. Characteristics of sampled households (dummy variables).

\begin{tabular}{lcrc}
\hline Variable & Category & Number & \% \\
\hline Educational status & Illiterate & 166 & 70.64 \\
& Literate & 69 & 29.36 \\
Access to credit & No & 91 & 38.72 \\
& Yes & 144 & 51 \\
Improved seed & Yes & 120 & 49 \\
& No & 115 & 51 \\
\hline
\end{tabular}

Source: Own computation of survey data (2018).

The average age of the respondents was 40.2 years (range: 18 - 75 years) (Table 4). The respondents had an average of 8 years of experience in tomatoes production (range: 1 - 27 years). Average one-year lagged price of tomato was 4.44 birr and it ranged from 2 to 6 birr per kilogram.

Table 4. Sample household characteristics (continuous variables).

\begin{tabular}{lrrrr}
\hline Variables & Mean & SD & Min & Max \\
\hline Age (years) & 40.20 & 11.41 & 18 & 75 \\
Distance to nearest market (hours walking) & 1.30 & 0.56 & 0.08 & 3 \\
Land size for tomatoes (hectare) & 0.33 & 0.19 & 0.06 & 1 \\
Non/off farm income (birr) & 15477.23 & 11162.16 & 2000 & 60,000 \\
Livestock ownership (TLU) & 5.47 & 3.08 & 0 & 20.38 \\
Tomato farming experience (years) & 8.21 & 5.29 & 1 & 27 \\
Lagged price (birr) & 4.44 & 0.90 & 2 & 6 \\
\hline
\end{tabular}

Source: Own computation of survey data (2018)

Sample households had an average of 5.5 livestock measured in tropical livestock units (TLU). Average household size of sample households was 2.7 persons (in adult equivalent). Sampled farm households cultivate tomato on an average on 0.33 ha of farmland. Sample households generated an average of 15477.2 birr per year from non-farm/off-farm income-generating activities, and it ranged from 2,000 to 60,000 birr.

\section{Determinants of tomato market supply}

Before the interpretation of model coefficients, assumptions of the classical linear regression (CLR) were conducted. For econometrics analysis, multiple linear regression model (OLS) was appropriate to analyze factors affecting marketed surplus of tomatoes because all sampled households producing tomato participated in marketing of tomatoes. If some of the assumptions of the classical 
linear regression (CLR)) model are violated, the parameter estimates of the model may not be the best linear unbiased estimator (BLUE). Thus, heteroscedasticity, multicollinearity, endogeneity, and model specification error test (test for omitted variables) were all checked before fitting important variables into the regression models.

Multicollinearity problem arises due to a linear relationship among explanatory variables. It becomes difficult to identify the separate effects of independent variables on the dependent variable because there exists strong relationship among them (Gujarati, 2003). VIF was employed to test for multicollinearity among explanatory variables and the result showed that the mean VIF was 1.19 which indicates no problem of multicollinearity among explanatory variables in the model. Breusch- Pagan/Cook-Weisberg test for heteroscedasticity was used and the result indicated that heteroscedasticity was a problem. The problem was corrected by applying robust standard errors. The regression specification error test was employed to test omitted variables, the result of which showed no omitted variables in the model $(\mathrm{F}=0.4637)$.

The problem of endogeneity occurs when an explanatory variable is correlated to the error term in the population data generating process, which causes, the ordinary least squares estimators of the relevant model parameters to be biased and inconsistent. The source of endogeneity could be omitted variables, measurement error, and simultaneity (Maddala, 2001). Both the Hausman test and Durbin-Wu-Hausman (DWH) test were applied to check the presence of endogeneity. Both test results of endogeneity showed that tomato farming experience was exogenous variable for tomato supply to the market, i.e., there was no endogeneity problem among explanatory variables. The method involves two successive applications. The first stage is made by regressing the suspected endogenous variables over the pre-determined or pure exogenous variables to get their predicted values. Then the predicted values of the endogenous variables in the first stage are used to estimate the supply equation. Here age (agehh) was used as an instrument to quantity of tomato farming experience. This instrumental variable was selected from the available variables by checking the correlation between an endogenous variable and the instruments and the model was specified as:

$\mathrm{Y}($ toputS $)=f($ educstatus LsizeT NFI isvstowneship Acrdt ISEED Disnmkt LP (TOfexp= agehh)

For this study 10 (ten) explanatory variables were hypothesized as factors affecting farm household level market supply of tomatoes. From these, six variables were found to be significantly affecting market supply of tomato. Land size allocated for tomatoes, accesses to credit, income from non-farm/off-farm 
and using improved seed influenced market supply of tomato. The F-test calculated value $\mathrm{F}(9,225)=36.75$ and the adjusted $\mathrm{R}^{2}$ was $62.92 \%$ implying that $62.92 \%$ of the variation in the dependent variable was explained by the explanatory variables under consideration.

Land size allocated for tomato: the result showed that land allocated for has significant positive effect on tomato market supply at 5\% significance level. An increase in the size of one hectare of land allocated for tomato increases quantity of sales of tomatoes by 18.86 quintals, keeping other factors affecting tomato market supply constant. The positive sign of the coefficient implies that the larger the land size allocated for tomato production, the larger the quantity produce and thereby increasing the quantity of produce available for sale. Thus, the per-unit production costs will be lower due to the economics of scale. Similar results were reported before (Kindie Aysheshim, 2007; Bosena Tegegn, 2008; Addisu Hailu and Melkamu Bezie et al. , 2017 ; Dibaba Regasa, 2018) the area of land allocated affected farm level market supply significantly and positively (Table 5).

Improved seed: the result indicated that use of improved seed had positive and significant influence on market supply of tomato at $\alpha=5 \%$. Households who used improved varieties of tomato seeds had a better chance to increase their market supply by 4.1 quintal than those who do not use improved varieties of tomatoes seed, keep other variables constant. Improved seeds were associated with high productivity level. Farmers who used improved variety of tomato could increase productivity thereby increasing the quantity of produce available for sale (Table $5)$.

Access to credit: the study result indicated that access to credit had positive and significant influence on market supply of tomato at $\alpha=5 \%$. Households with better access to loan had better chance to increase their market supply by 5.43 quintal than those who do not have access. Most of the time, access to credit in the households is determined by cash on hand that is usually used for purchasing improved varieties, fertilizers, chemicals, and labor wages. The result was consistent with other studies (Abraham, 2013; Mahlet Abitew et al., 2015; Addisu Hailu and Melkamu Bezie et al., 2017) whose results indicated access to credit positively and significantly affected the market supply of a commodity (Table 5).

Income from non-farm /off-farm: had a positive and significant influence on the market supply of tomato at $\alpha=1 \%$. The coefficient indicates as income from non -farm/off-farm activities increase by one birr, the quantity of tomato supplied to market increased by 0.0014 quintals, keeping other factors constant. 
Table 5. Determinants of tomatoes marketed surplus.

\begin{tabular}{lll}
\hline Variables & $\begin{array}{l}\text { Coefficients } \\
(\mathrm{dy} / \mathrm{dx})\end{array}$ & $\begin{array}{l}\text { Robust Standard } \\
\text { error }\end{array}$ \\
\hline Educstatus & -2.0457 & 1.6779 \\
TOfexp & -0.0853 & 0.1589 \\
LsizeT & $18.8663^{* *}$ & 8.0962 \\
ISEED & $4.0642^{* *}$ & 1.8863 \\
Lisvstowneship & $-0.8196^{*}$ & 0.4953 \\
Acrdt & $5.4321^{* *}$ & 2.2053 \\
NFI & $0.0014^{* * *}$ & 0.0002 \\
Disnmkt & 2.9937 & 1.8625 \\
LP & 1.1974 & 1.1334 \\
Agehh & 0.1109 & 0.0738 \\
Constant & -10.0418 & 8.2124 \\
& & \\
Observations & 235 & \\
R-squared & 0.6457 & \\
Adj R2 & 0.629 & \\
F $(10,224)$ & 0.4083 \\
Multicollinearity (mean VIF) & 1.19 \\
Heteroskedasticity (prob $>$ Chi $\left.{ }^{2}\right)$ & 0.00 & \\
Model specification (Ovtest) & 0.46 \\
Endogeneity test (Durbin score) Chi ${ }^{2}(1)$ Wu- & $1.50443(\mathrm{p}=0.2200)$ \\
Hausman F (1,224) & $1.44325(\mathrm{p}=0.2309)$ \\
\hline$* * *, * *$ and * show the values statistically significant at $1 \%, 5 \%$, and $10 \%$ significance \\
level, respectively.
\end{tabular}

This may be due to the fact that farmers who had cash from these sources used as a supplementary income to purchase inputs like improved seed, fertilizers, chemicals and farm implements for tomato production and thus supplied more tomato to the market than those who had not. This result is consistent with previous studies (Abraham Tegegn, 2013 ; Melkamu Bezie et al., 2017) who indicated that non - farm / off-farm income influenced market supply positively and significantly at $1 \%$ significance level. This result is consistent with Adenuga et al. (2012) who found that non- farm/off-farm income influenced the volume of maize supplied to market positively and significantly. They stated that farmers with an additional source of income will be willing to take risk in producing more for the market (Table 5).

Livestock holding: unexpectedly, this variable had a significant and negative relationship with the quantity of tomatoes supplied to the market. The reason may be households who own more livestock allocate their land to cereal crops to produce feed as a joint product. They may also use their land for grazing which 
could decrease land available for tomatoes production. The coefficient indicated as livestock holding increases by one TLU, the quantity of tomato supplied to the market decreased by 0.81 quintals, keeping constant other factors which affect tomato market supply. Livestock holding significantly and negatively influenced quantity of potato supplied to markets (Mahlet Abetew et al., 2015; Bekele Wegi, 2017), but also significantly positive relationship (Melkamu et al., 2017).

\section{CONCLUSION}

The multiple linear regression model indicated that market supply of tomato was significantly affected by land allocated for tomato, use of improved seeds, livestock ownership, access to credit and cash income from non-farm / off-farm activities. All of these variables affected the market supply of tomatoes positively except livestock ownership. Therefore, the policy implications are increasing the production and productivity of tomato per unit area of land using improved technologies, improved tomatoes seed varieties, investment on off/non-farm income-generating activities, facilitating credit access for the agricultural production activities so as to increase the market supply of tomatoes in the study area.

\section{Availability of data and materials}

Data generated and used in this study is available in the records of the author and could be made available upon request.

\section{Competing of interest}

We the authors declare that there is no conflict of interest.

\section{Funding statement}

The research was funded by the college of Agriculture and Environmental Science of Bahir Dar University and BDU-IUC program.

\section{Authors' contribution}

Hawlet Mohammed designed the study, collected the data with enumerators, analyzed the data, and wrote the manuscript. Zewdu Berhanie designed the study, helped in data analysis and proofread the manuscript. Getachew 
Alemayehu helped in funding the research (for collecting the data) and proofread the manuscript.

\section{ACKNOWLEDGMENTS}

The authors express special gratitude to the BDU-IUC Program and Ministry of Education for the research funding. Our extended gratitude also goes to enumerators for their support in data collection and to farmers for their participation during the survey.

\section{REFERENCES}

Abu Tefera and Teddy Tefera (2013). Tomato production in Ethiopia challenged by pest. USDA Foreign Agricultural Service, Global Agricultural Information Network (GAIN). Addis Ababa, Ethiopia, 6-27-2013.

Abay Akalu (2007). Vegetable market chain analysis in Amhara National Regional State: the case of Fogera district, South Gondar Zone, MSc Thesis, Haramaya University, Haramaya, Ethiopia.

Abreham Tegegn (2013). Value chain analysis of vegetables: The case of Habro and Kombolcha district in Oromiya Region, Ethiopia. MSc Thesis, Haramaya University, Haramaya, Ethiopia, 144 pp.

Addisu Hailu (2017). Determinants of volume sales among smallholders potato farmers in Ejere district, West Shoa Zone, Oromia Region. Journal of Economics and Sustainable Development 8(5): 87-95.

Astewel Takele (2010). Analysis of rice profitability and marketing chain: The case of Fogera district, South Gondar Zone, Amhara National Regional State, Ethiopia. MSc Thesis, Haramaya University, Ethiopia. 76 pp.

Bekele Wegi (2017). Econometric analysis of the determinants of quantity of potato supplied to the market: The case of Jeldu district of Oromia National Regional State, Ethiopia. Journal of Economics and Sustainable Development 8(13): 49-57.

Bosena Tegegn (2008). Analysis of cotton marketing chains: The Case of Metema district, North Gonder Zone, Amhara Regional State. MSc Thesis, Haramaya University, Haramaya, Ethiopia. 110 pp.

Chala Hailu and Chalchisa Fana (2017). Determinants of market outlet choice for major vegetables crop: Evidence from smallholder farmers of Ambo and Toke-Kutaye districts, West Shewa. International Journal of Agricultural Marketing 4(2): 161169.

CSA (Central Statistical Agency) (2007). Ethiopia population and housing census. CSA: Addis Ababa, Ethiopia.

CSA (Central Statistical Agency) (2015). Large and medium scale commercial farms sample survey results. Statistical report on area and production of crops, and farm (private peasant holdings, Meher Season). CSA, Addis Ababa, Ethiopia, VIII.

Desta Bayera (2004). Impact of community managed irrigation on farm production efficiency and household income. The case of Weliso and Wenchi districts of 
Oromiya Regional State, MSc Thesis, Haramaya University, Ethiopia.

Dibaba Regasa (2018). Factors affecting market supply of wheat by smallholder farmers in Ethiopia. Journal of Natural Sciences Research 8(19): 56 - 64.

Efa Gobena and Tura Kaso (2018). Determinants of tomato smallholder farmers market outlet choices in West Shewa, Ethiopia. Journal of Agricultural Economics and Rural Development 4(2): 454-460.

EIA (Ethiopia Investment Agency) (2012). Investment opportunity profile for the production of fruits and vegetables in Ethiopia. Addis Ababa, Ethiopia.

FAOSTAT (2009). FAOSTAT (Food and Agricultural Organization Statistical Division). Preliminary 2008 data for selected countries and products, http://faostat.fao.org/site/567/,https://doi.org/10.1017/CBO9781107415324.004.

Fogera District Agricultural Office (2015). Socio-economic profile description of Fogera district of North Gondar, Woreta, Ethiopia.

Getaneh Gizachew (2005). Dairy marketing patterns and efficiency: The case of Ada Liben district, Eastern Oromia. MSc Thesis, Haramaya University, Haramaya, Ethiopia.

Gujarati, D.N. (2003). Basic Econometrics. 4th Edition. McGraw-Hill, New York.

Kindie Aysheshim (2007). Sesame market chain analysis: The case of Metema district, North Gonder zone, Amhara Region, Ethiopia. MSc Thesis, Haramaya University, Haramaya, Ethiopia.

Maddala, G.S. (2001). Introduction to Econometrics. Macmillan, New York.

Mahlet Abitew, Bezabih Emana, Mengistu Ketema, Jeffreyson, K and Jemal Yousuf (2015). Gender role in market supply of potato in Eastern. African Journal of Agricultural Marketing 3(8): 241-251.

Mebrat Tola (2014). Tomato value chain analysis in the Central Rift Valley: The case of Dugda district, East Shoa Zone, Oromia National Regional State, Ethiopia. MSc. Thesis, Haramaya University, Haramaya, Ethiopia.

Melkamu Bezie, Degye Goshu and Bosena Tegegn (2017). Determinants of potato marketed surplus among smallholder farmers in Banja district, Awi Zone of Amhara Email address. International Journal of Agricultural Economics 2(4): 129-134.

Hawlet Mohammed, Zewdu Birhane and Getachew Alemayehu (2019). Determinants of market outlet choice decision of tomato producers in Fogera district, South Gonder zone, Ethiopia. Cogent Food and Agriculture 5(1): 1- 20.

Nuri Lefebo (2016). Value chain analysis of enset (Ensete ventricosum) in Hadiya Zone, Southern Ethiopia. PhD Thesis, Haramaya University, Haramaya, Ethiopia.

Rehima Mussema (2006). Analysis of red pepper marketing: The case of Alaba and Siltie in SNNPRS of Ethiopia. MSc Thesis, Haramaya University, Haramaya, Ethiopia. 133 pp.

Thakur, D.S., Harbans, Lal, Thakur, D.R., Sharma, K.D and Saini, A.S. (1997). Market supply response and marketing problems of farmers in the hills. Indian Journal of Agricultural Economics 52(1): 139-150.

Willcox, J.K., Catignani, G.L and Lazarus, S. (2003). Tomatoes and cardiovascular health. Critical Reviews in Food Science and Nutrient. Advances in Medicinal Plant Research 43: 1-18.

Yamane, T.(1967). Statistics: An Introductory Analysis. Harper \& Row, New York, Evanston \& London and John Weatherhill, Inc., Tokyo.

Yeshitila Alemu (2012). Analysis of vegetable marketing in Eastern Ethiopia: The case of 
potato and cabbage in Kombolcha district, East Hararghe, Oromia National Regional State. MSc Thesis, Haramaya University, Haramaya, Ethiopia. 